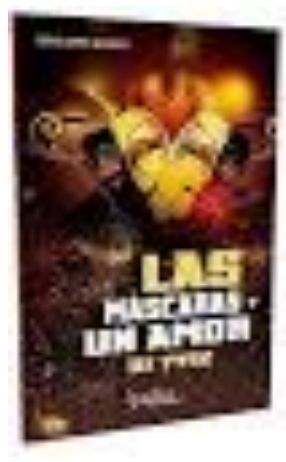

RESENHA: LOPEZ VELASCO, Sirio. Las máscaras y Un amor de 1492. Goiânia: PHILLOS, 2019, 219p [ISBN 978-65-5071-012-5]

\title{
Las máscaras y Un amor de 1492
}

José Alberto de fa Fuente ${ }^{1}$

Las Máscaras, es una novela que recrea la sofisticación de los conflictos existenciales, acaecidos al interior de la alta academia universitaria, donde los filósofos estudiosos de la construcción y efectos del pensamiento de ilustres camaradas de oficio, reflexionan, se informan y discuten enmascarando sus propios dislates amorosos, en encuentros solemnes y organizados, agregando una pizca de turismo académico y una cuota de suspenso "por todas esas muertes".

Es una novela que podría calificar de ágil, entretenida, del gótico tardío del siglo XVIII, cuya trama abierta y sin comentarios moralizantes, motiva al lector para que llegue a pensar que el erotismo entre académicos es un laberinto hacia el nihilismo. El espacio socio-cultural que dinamiza el relato, remite a las muertes de distintos profesores en los sitios y en las fechas del Carnaval de Venecia; los personajes protagonistas son investigadores universitarios que no han integrado, con la misma reciedumbre existencial, una vivencia de soledad que se les va convirtiendo en la peor de las compañías. Las Máscaras, después de haber leido la novela de "un tirón", considero que es una de las mejores obras de Sirio López, deslindando por cierto otras marcas y senderos narrativos.

No es sencillo saber o apostar que su narrador (en tercera persona, indirecta y estilísticamente libre) posee un sutil y agudo escalpelo de ironía y humor. Novela redonda, simpática, abierta, rompe con la escritura conceptual que tiende al hermetismo y al distanciamiento. En el texto, los personajes novelescos son los

'Professor Doutor da Universidad de Santiago de Chile. E-mail: josepepe.delafuente@gmail.com. 
filósofos; por su parte, los "investigadores" son el entorno socio-universitario que hace que uno de ellos asuma el oficio de policía ¿El mundo al revés? La academia aparece tan banal, a veces insensata, cuyos relieves afectivos han quedado relegados a los estupefacientes, al alcohol y a las relaciones amorosas pedestres e insensatas, de emocionar casi invisible e insuficiente, que no es lo enteramente visible para aquilatar el pensamiento inhabitual. En la historia de la teoría y de la crítica de la literatura, la máscara es el símbolo del verdadero y auténtico rostro de la realidad humana. Sus rasgos, sus facciones, constituyen aquello que se ve (sin dejarse ver a simple vista) y que se mantiene escondido. Es el secreto del alma revelado de manera indirecta, el "decir sin decir", lo más propio del Arte Verbal que hasta la actualidad nos remite a las representaciones de la tragedia griega.

La máscara es el rostro que no miente. En la novela, el "personaje" homenajeado es Jan Paul Sartre, identidad que se va construyendo en las comunicaciones de los invitados al simposio, en temas como: El ser y la nada Ensayo de ontología fenomenológica, El existencialismo es un humanismo, Sartre, Simone de Beauvoir y la mujer (Anne), La sinceridad y la autenticidad, etc. ¿Las preguntas que se hacen los filósofos son para que las respondan los muertos? ¿es posible la verdad, decir la verdad, alcanzarla en su totalidad hasta llegar al paraíso de la sinceridad? ¿Quién es, en definitiva, el narrador que pretende desentrañar lo que hay al otro lado del espejo? ¿El profesor Claudio Silva? En consecuencia, la novela Las Máscaras, en su dimensión dialógica, es un relato que nos permite concluir que solo se puede decir y encontrar la verdad en las obras de ficción. La verdad se registra exclusivamente en este espacio y no fuera de la literatura, porque la literatura y el arte son la convergencia, resolución y fusión de eso que nos han querido convencer por miles de años ¿No es lo que dice el personaje Urbino, en la página 39? Ficción y realidad no son opuestos, simplemente la ficción no es más que uno de los recursos de la imaginación, que nos permite acceder a la totalidad, en el horizonte de nuestras percepciones y límites.

Un amor de 1492, emerge hacia un lenguaje descriptivo y realista que recrea el proyecto novelesco de un Zolá y de un Victor Hugo, cuando pensaron y explicaron cómo debería ser la novela experimental en su dimensión testimonial narrada en primera persona, autobiográfica e histórica, cuyo sustrato fantástico es una elocuente apelación a lo real. No obstante, en esta novela están muy bien decantadas las anécdotas, las peripecias de los protagonistas en la diáspora de los pueblos perseguidos (judíos) y muy bien equilibrada la línea argumental de fondo el amor de una pareja, Sara y Emilio- con los avatares de los migrantes, sus familias, sus nacimientos y peligros en el contexto de una España de tabúes dosificados por la atmósfera de un cristianismo que, al poco andar en la historia grecorromana, viene a enrarecer toda la vida social y política ulterior de Occidente. Sara es un personaje que casi no habla; Emilio, una personalidad que se construye y salvaguarda en la 
identidad de su amada; Yohai, el médico o curandero que no está de acuerdo con el edicto de los reyes Fernando e Isabel, es el observador empírico de cómo se expresa la naturaleza en los cuerpos. Su cultivo del damasquinado es la voz de la tradición. David, el fiel y aparente resignado judío que se debe a su familia y a su credo, se abre a los más excluyente de la época, acepta sin más la diferencia en la religión del "otro"; los gitanos, que por resistirse a cualquier tipo de adocenamiento social, se establecen en aduares como ciudadanos del mundo, huyendo y pernoctando, en todos los territorios para reconocerse en todos y en ninguno.

La forma de la novela responde a una dosificación de párrafos descriptivos que, en algunos pasajes de la mitad hacia el final, tienden a una cierta extensión que pone en riesgo la relevancia de los personajes. El lector va adentrándose en los motivos del relato como si fueran los minuciosos acontecimientos que configuran las anécdotas que se entretejen en la historia: descubrimiento de América, desciframiento de manuscritos; aparición de Yohai, el maestro y su discípulo; cómo lo antiguo se renueva al rememorarlo en el presente, el sentido de la vida de los tornadizos y el matrimonio; los lugares secretos donde Sara y Emilio hacen el amor;el muerto desconocido que llega a casa de Yohai; el 3 de marzo de 1492, fecha de la expulsión de los judíos de España; el día de la despedida hacia Valencia, los riesgos al vadear los ríos y cómo se forma la identidad de los perseguidos...en un mundo en que los arbitrios del poder se respaldan en creencias religiosas.Un amor de 1492, es una novela que entretiene, nos sitúa en la historia y adentra al lector en una historia de quinientos años de exclusión.

Submissão: 26. 12. 2019 / Aceite: 28. 12. 2019 